JEL Class K41, K42

September 4, 1998

\title{
Why Is the Japanese Conviction Rate So High?
}

\author{
J. Mark Ramseyer \\ Harvard Law School \\ Eric B. Rasmusen \\ Indiana University, Kelley School of Business
}

\section{Abstract}

Conviction rates are high in Japan. Why? First, Japanese prosecutors are badly understaffed. Able to bring only their strongest cases, they could be presenting judges only with the most obviously guilty defendants. High conviction rates would then follow naturally. Crucially, however, this is not the full story, for Japanese judges face seriously biased incentives. A judge who acquits a defendant runs significant risks of hurting his career and earns scant hope of positive payoffs. Using data on the careers and published opinions of 321 Japanese judges (all judges who published an opinion in a criminal case in 1976 or 1979), we find skewed incentives to convict. First, a judge who - trying a defendant alone -- acquits a defendant will spend during the next decade an extra year and a half in branch office assignments. Second, a judge who acquits a defendant but finds the acquittal reversed on appeal will spend an extra three years in branch offices. Conversely, a judge who finds a conviction reversed incurs no substantial penalty. Unfortunately for innocent suspects, the absence of an unbiased judiciary also reduces the incentives Japanese prosecutors have to prosecute only the most obviously guilty defendants.

Ramseyer: Harvard Law School, Cambridge, MA 02138. Email: ramseyer@law.harvard.edu. Office: (617) 496-4878. Fax: (617) 495-1110. Email: Ramseyer@law.harvard.edu.

Rasmusen: Indiana University, Kelley School of Business, Dept. of Business Economics and Public Policy, BU 456, 1309 E. 10th Street, Bloomington, IN 47405-1701. Office: (812) 855-9219. Fax: 812-855-3354. Email:

erasmuse@juno.com. Web:

Php.indiana.edu/ erasmuse.

We thank John Coates, John Lott, Setsuo Miyazawa, Arthur Rosett, Detlev Vagts, Mark West and participants at workshops at Harvard University, Kyushu University, Washington University St. Louis, and the University of Wisconsin for helpful comments. We received generous financial assistance from the Lynde and Harry Bradley Foundation, the Sarah Scaife Foundation, and the John M. Olin Foundation. 
Virtually every American law professor knows at least one fact about Japanese law: Japanese courts convict everyone tried. The puzzle is what to make of this. Perhaps Japanese judges convict because Japanese prosecutors try only the guilty. If so, then the high conviction rates would represent a phenomenon many people would envy. Or perhaps Japanese judges convict because they further their careers by convicting. Most defendants might still be guilty -- but then again they might not. Perhaps the law in its majestic equality offers, as Anatol France might have put it (nationality aside), the innocent and guilty alike the right to hang for crimes.

That Japanese prosecutors might do unusually well at trying only guilty defendants follows straightforwardly from budget constraints. Chronically understaffed, Japanese prosecutors lack the time to prosecute any but a small fraction of the suspects forwarded by the police. Rather than waste their time with dubious cases (other than the occasional politically driven corruption case), perhaps rational prosecutors prosecute only the most obviously and gruesomely guilty.

That Japanese judges might face skewed incentives follows from the bureaucratic structure of the Japanese courts. Usually, Japanese judges take their jobs straight out of the national law school. They then stay judges until they retire. During their career, they work as judicial bureaucrats: where they work and what they earn depends on the reputation they maintain with their judicial betters at the courts' administrative office.

Using data on the careers and published opinions of 321 judges (all judges who published opinions in criminal cases in 1976 or 1979), we find that Japanese judges do indeed face skewed incentives in criminal cases. They indeed do better if they convict than if they acquit. Suppose a judge sitting alone acquits a defendant. On average, he will spend an extra year and a half in branch offices over the next decade. Or suppose he finds a case reversed on appeal. If a high court reverses one of his convictions, he will suffer no significant penalty -- but if it reverses one of his acquittals, he will spend an extra three years in branch offices.

We begin by comparing conviction rates in Japan and the U.S. (Section I). We explain why the severe budget constraints in Japanese prosecutorial offices could result in a high ratio of guilty to innocent prosecutions (Section II). We then explore empirically the pressure Japanese judges face to convict (Section III).

\section{Comparative Conviction Rates:}

\section{A. The Rates:}

Conviction rates are high in Japan. They are high in most countries, of course, but they are particularly high in Japan. In 1995, federal courts convicted 85.1 percent of all defendants $(46,773$ out of 54,980) and 83.3 percent of murder defendants (265 out of 313). In the state courts, prosecutors win roughly 87 percent of their felony cases and 88 percent of their misdemeanors. In 1994, Japanese district court judges convicted 99.9 percent of all defendants $(49,598$ out of 49,643). Of the defendants up on murder charges, they convicted 99.7 (587 out of 589). ${ }^{1}$ If the U.S. attorney

${ }^{1}$ In a majority of Japanese murder cases, the charges against the suspect are dropped, as we discuss in Section II.B.2., below. For Japanese figures, see Homusho, Hanzei hakusho [White Paper on Crime] 122 (Tokyo Okura sho, 1996). The Saiko saibansho jimusokyoku, Shiho tokei nempo, Heisei 6-nen [Annual Report of Judicial Statistics, 1994] (Tokyo: Hosokai, 1994) gives slightly different figures. For U.S. federal courts, see Administrative Office of the U.S. Courts, Judicial Business of the U.S. Courts tab. D-4 (Washington, D.C.: Administrative Office of the U.S. Courts, 1995) (murder includes 1st and 2d degree; figures -- 10/94-9/95). For state courts, see U.S. Dept. of Justice, Bulletin - Prosecutors in State Courts, 1994 (1996, NCJ-151656). 
goes after you, you had better hire a good lawyer; if a Japanese prosecutor does, you had better pack for prison.

\section{B. Uncontested Proceedings:}

1. Introduction.

Conviction rates like 83.3 or 99.7 percent are not the odds that a defendant who contests his guilt actually faces, either in the U.S. or in Japan. The data for both countries include cases where defendants decided not to contest the charges. In Japan, to be sure, the law does not allow plea bargains. Instead, all defendants prosecuted face trial, and courts convict them only if prosecutors prove their guilt beyond a reasonable doubt.

Yet the lack of formal plea bargains in Japan does not mean the parties ignore analogous calculations. Defendants need not contest their guilt. Instead, they can freely confess. In exchange, prosecutors can freely suggest a sentence lower than the sentence the defendant would receive at a contested trial. The suggestion matters, because courts routinely accept the recommended sentence. $^{2}$ To be sure, such an implicit bargain would not be enforceable formally. Still, both sides will generally find it binding in fact. If only to encourage defendants to confess, the prosecutor's office will want to maintain its reputation for playing by customary norms. Having already confessed, the defendant would find it hard effectively to renege even if he wanted. ${ }^{3}$

\section{Confessions in Japan.}

For both the prosecutor and the defendant, uncontested proceedings present straightforward gains from trade. ${ }^{4}$ By agreeing not to contest his guilt, a defendant saves the prosecutor resources he can use to prosecute others. So long as the deterrent effect of these additional convictions outweighs the savings to the settling defendant, the arrangement increases the deterrent value of the law. Perhaps more important, it increases the prosecutor's observable work product -- the productivity he can show his present bureaucratic supervisors and future private-sector employers. The gains to the defendant are equally obvious. So long as the prosecutor demands a sentence less costly than the sum of (a) the expected risk-adjusted value of the sentence from a contested trial and (b) the defendant's expected litigation costs -- so long as he demands such a sentence, the defendant gains from not contesting prosecution.

Absent an explicit or implicit bargain, rational defendants gain little by confessing. Perhaps some defendants confess or plead guilty without some promise of a lower penalty. Exceptions do not prove rules, however, and we have little reason to think defendants anywhere systematically act against their self-interest. If Japanese defendants routinely file confessions, that very fact suggests that they routinely receive lower sentences as a result.

${ }^{2}$ Daniel H. Foote, The Benevolent Paternalism of Japanese Criminal Justice, 80 Cal. L. Rev. 317, 352 (1992). For an analogous debate in the German context, see John Langbein, Land Without Plea Bargaining: How the Germans Do It, 78 Mich. L. Rev. 204, 214-15 (1979).

${ }^{3}$ Where lack of enforceability matters is in plea bargains in which the defendant wishes to promise cooperation as a witness in other cases. In such bargains, the cooperation sometimes comes after the prosecutor has recommended a sentence, and U.S. prosecutors, keenly aware of the potential for defendant breach, use all the formal legal tools at their disposal to prevent it. See, for example, Eric Rasmusen, Mezzanatto and the Economics of Self Incrimination, 19 Cardozo L. Rev. 1541 (1998). Lack of enforceable plea agreements, like low budgets, is an obstacle in the path of the Japanese prosecutor.

${ }^{4}$ This approach was pioneered by Frank Easterbrook, Criminal Justice as a Market System, 12 J. Leg. Stud. 289 (1993). 
Japanese defendants certainly do confess. Of the 49,856 criminal cases in Japanese district court in 1994, defendants contested prosecution in only 7.3 percent. If a confession generally represents a functional analogue to a plea bargain (obviously, they are not exact equivalents), then Japanese defendants cut a bargain nearly 93 percent of the time. By contrast, of the 54,980 criminal cases in U.S. federal district courts in 1995, defendants pleaded innocent in 22 percent. In the state courts, they pleaded innocent in 11 percent. Notwithstanding the formal absence of plea bargains, Japanese defendants are modestly more likely not to contest prosecution than Americans. ${ }^{5}$

3. The logic to the comparative rates.

The somewhat lower frequency of contested prosecutions in Japan probably reflects the greater predictability of trials there. The logic follows from the well-known model of litigation and settlement. ${ }^{6}$ A prosecutor faces lower costs if he can simply meet with the defendant's lawyer and bargain than if he must prove his case in a contested trial. A defendant similarly saves time and expense by using private negotiations rather than a trial. By bargaining, moreover, both sides avoid risk -- exchanging a gamble between conviction with a higher sentence and acquittal with none for a definite, agreed-upon sentence. If both sides similarly estimate the odds of the various trial outcomes, then unless one of them enjoys risk they will prefer to plea bargain. Even if they do not agree completely on the odds, so long as their opinions are close enough and the cost and risk of trial are high enough, they will prefer to cut a deal.

In Japan, two factors dramatically increase the predictability of criminal litigation compared to what happens in the U.S. ${ }^{7}$ First, trials are discontinuous. The prosecutor and defendant begin the trial by assembling before a judge. They discuss the issues at stake and then recess to gather evidence. Having collected evidence on the first issue, they reconvene, litigate that issue, and recess again to gather evidence on the next. In the process, the judge has considerable chance to disclose how he leans. As he discloses his inclinations, the parties obtain increasingly accurate estimates of the outcome at trial.

Second, all trials are bench trials. Unlike juries, judges have "seen it all before" -- and the lawyers have seen them seeing it. The judges have histories that lawyers can investigate to find out how they approach cases. Whether because they take professional pride in uniformity, or because (like most mortals) they economize on effort, judges tend to decide similar cases similarly.

This predictability reduces the variance in the prosecutor's and defendant's estimates. Plea bargains fail and litigation ensues when both parties are optimistic -- where the difference in their estimates of the contested outcome is so great that they cannot agree to meet in the middle and save their trial costs. To the extent that predictability of the judicial system reduces the variance in their estimates, it reduces the frequency with which prosecutors and defendants will arrive at dramatically different estimates. And -- to restate the point earlier -- if their estimates are close, they will prefer to cut a deal.

${ }^{5}$ See Saiko saibansho, supra note 1, at vol. 2, tab. 31-4 (excluding traffic crimes); Administrative Office, supra note 1, at tab. D-4; U.S. Dept. of Justice, Bulletin - Felony Sentences in State Courts (1997, NCJ 163391).

${ }^{6}$ The earliest discussions of the model include William M. Landes, An Economic Analysis of the Courts, 14 J. L. \& Econ. 61 (1971) and Richard A. Posner, An Economic Approach to Legal Procedure and Judicial Administration, 2 J. Legal Stud. 399 (1973).

${ }^{7}$ See J. Mark Ramseyer \& Minoru Nakazato, The Rational Litigant: Settlement Amounts and Verdict Rates in Japan, 18 J. Legal Stud. 263 (1989). 
All this is not just theory. Instead, evidence from civil suits corroborates this explanation for Japanese settlements. ${ }^{8}$ As observers often note, disputants in Japan seem to settle a larger fraction of civil disputes than in the U.S. They settle them, however, in the shadow of the law. Out of court, defendants pay and plaintiffs collect amounts that track the amounts a court would award. They settle for a simple reason: because the trial outcome is usually clear, neither side has any reason to bother litigating. Rather than sue, they settle out of court along the lines that they expect a judge to rule if they did sue.

4. Residual conviction rates.

Given the higher rate of uncontested proceedings in Japan, what is the residual conviction rate in contested cases? How does it compare to the rate in the United States? The contrast is stark. In 1994 Japanese defendants refused to confess in 3,648 cases. Courts acquitted them in 45, yielding a contested conviction rate of 98.8 percent. In 1995, U.S. federal defendants pleaded innocent in 11,877 cases. Courts acquitted them (or dismissed the charges) in 8,207, yielding a contested conviction rate of 30.9 percent. ${ }^{9}$ In state courts, the contested conviction rate apparently stands even lower. ${ }^{10}$

\section{Prosecutorial Incentives:}

\section{A. Introduction:}

For a scholar, why conviction rates might be high is a bedeviling puzzle. They might be high because prosecutors only prosecute the guilty, and judges then duly convict. Or they might be high because judges dutifully convict everyone prosecuted, guilty or no. To determine which might be true (or whether both are true, or perhaps neither), a scholar would seem to need independent evidence of the guilt of the accused. That, of course, is information only God and the Shadow ever have.

As a simple heuristic, consider Figure 1. In this summary, prosecutors can screen suspects carefully or cursorily. The courts, in turn, can decide the cases fairly (carefully and without a proconviction bias) or unfairly (either cursorily or with bias). ${ }^{11}$

If a prosecutor screens suspects carefully, then whether a court reviews cases fairly (row (a)) or unfairly (row (b)), conviction rates will be high and few innocent defendants will be convicted. If a prosecutor screens only cursorily, then if a court reviews cases fairly it will periodically acquit (row (c)). Conviction rates will be lower, but here too few innocent defendants will stand convicted. If a court merely rubber-stamps prosecutions, however, then conviction rates will remain high and innocent defendants may indeed comprise a substantial fraction of those convicted (row (d)).

The puzzle is which case best describes Japan. Given the high conviction rates, it cannot be row (c). But which among the others might it be? Is it the intuitively troubling row (d), or one of the apparently less problematic rows (a) or (b). Lacking independent evidence of the guilt of the

\footnotetext{
${ }^{8}$ See Ramseyer \& Nakazato, supra note 7.

${ }^{9}$ Saiko saibansho, supra note 1, at tabs. 31-4, 36-3; Administrative Office, supra note 1, at tab. D-4. If we ignore dismissals, defendants were acquitted in 1,095 of the 4,765 trials in the U.S. -- a conviction rate of $77.0 \%$.

${ }^{10}$ A point implied by federal surveys placing both the aggregate conviction rate and the plea bargaining rate in the high 80 percent range. See U.S. Dept. of Justice, supra note 1 and supra note 5.

${ }^{11}$ Hypothetically, of course, courts could also have a pro-acquittal bias. Given that no one has suggested such a phenomenon in Japan, we ignore the possibility here.
} 
suspects, we cannot test the issue directly. To explore it indirectly, we instead proceed in two steps. We first explore the likely effect of the resource constraints on prosecutorial screening (this Section II). We then test empirically whether judges in Japan face unbiased incentives (Section III).

Figure 1 - Prosecutorial Screening and Judicial Review

\begin{tabular}{ccccc} 
& $\begin{array}{c}\text { Prosecutorial } \\
\text { Screening }\end{array}$ & $\begin{array}{c}\text { Judicial } \\
\text { Review }\end{array}$ & $\begin{array}{c}\text { Conviction } \\
\text { Rates }\end{array}$ & $\begin{array}{c}\text { Innocents } \\
\text { Convicted }\end{array}$ \\
\hline & High & Yes & Higher & Fewer \\
(a) & High & No & Higher & Fewer \\
(b) & Low & Yes & Lower & Fewer \\
(c) & Low & No & Higher & More \\
(d) & & & & \\
\hline
\end{tabular}

B. The Story:

1. The intuition.

One need not posit clairvoyance to suggest that there might be a difference in the ratio of innocent to guilty defendants in Japanese and American courts. Instead, one need only show a difference in prosecutorial budgets. Suppose, as seems likely, a prosecutor promotes his career by convicting defendants. A win helps; a loss is at best neutral, and even then suggests he wasted time he might have used to obtain more convictions.

But how does a prosecutor win cases? The obvious answer is by being brilliant, experienced, and thoroughly prepared. There is an easier way, however: just prosecute slam-dunk cases. By only filing cases with overwhelming evidence, the prosecutor can avoid ever losing except by accident. Or, if averse to even a small chance of losing, he can offer such generous plea bargains that no rational defendant would ever plead innocent.

Things are not so simple, of course. Given bureaucratic pressures, a prosecutor cannot maximize his current conviction rate by prosecuting and winning one petty larceny case, telling the police to forget about all their other arrests, and then relaxing in Hawaii till next January. Rather, he must at least keep busy, and he faces some pressure from police and public to convict as many criminals as possible.

Given these pressures, a prosecutor has strong incentives to prosecute mostly strong cases. As a Tokyo prosecutor once put it, "Prosecutors regard acquittal as a very serious problem. ... Each prosecutor examines each case very, very carefully, and if he doubts that it's a strong case - or if there are extenuating circumstances - he doesn't indict." ${ }^{22}$ A prosecutor will always have more cases than he has time to handle. ${ }^{13}$ Rationally, he will turn to his strongest cases first. In exceptional circumstances, he will try evidentially weak cases involving politically visible or

\footnotetext{
${ }^{12}$ Quoted in Cynthia Mayer, Japan: Behind the Myth of Japanese Justice, Am. Law. July/Aug. 1984, at $113,119$.

13 This is not accidental. Any justice system in which prosecutors have the resources to prosecute every possible case is grossly overfunded. It is more efficient to prosecute only a fraction of cases, and usually only the strongest cases. If a criminal cannot determine in advance whether he will be one of those prosecuted, such a system preserves deterrence and reduces costs. This is one corollary of the large-punishment-with-low-probability theory of Gary S. Becker, Crime and Punishment: An Economic Approach, 76 J. Pol. Econ. (1968).
} 
particularly heinous crimes. Usually, though, he will start with the most straightforward cases and move to the more problematic only as time permits. He will first take the cases of a given seriousness that have the highest probability of conviction, and move to cases with lower conviction odds only as resources allow. ${ }^{14}$

By this dynamic, a prosecutorial office with a lower budget (Japan, in our analysis) may have a higher conviction rate than its better-funded peers (the U.S.). Given its more severe resource constraints, the leaner office will have time to prosecute only the most egregious cases. In the extreme, a resource-starved office may only be able to prosecute one case a year, and have a conviction rate of 100 percent -- even though the prosecutor still lacks time for the trip to Hawaii. Given its more generous resources, a fatter office will be able to move to riskier cases, but will find its conviction rate lower. ${ }^{15}$

\section{Comparative statistics}

Consider a few back-of-the-envelope comparisons. ${ }^{16}$ To deal with its legal affairs, the U.S. federal government employs 27,985 lawyers and the various state governments 38,242 (of which 24,700 are state prosecutors). The entire Japanese government employs 2,000.

Notwithstanding the difference in population and crime rates between Japan and the U.S. (and with appropriate caveats about the comparability of the statistical categories), this difference in personnel generates significantly higher workloads in Japan. Each year, police in the U.S. make about 12 million arrests (excluding many of the traffic offenses). Given that there are 25,000 state prosecutors, that comes to 480 arrests per year per prosecutor. Because many of the 28,000 federal lawyers also prosecute crimes, this figure overstates the actual prosecutorial work load. Of the 12 million arrests, the FBI catalogs 2.4 million as "serious crimes." Even if only state prosecutors handled all those cases, they would still have merely 96 serious criminal arrests apiece.

By contrast, in any given year Japanese police make about 1.4 million arrests for Criminal Code violations. They make another 1.1 million for other (mostly traffic) crimes. This of course comes to 1250 total arrests per prosecutor. If we exclude traffic offenses, it comes to 700 .

Differences in clearance rates reflect these differences in workload. ${ }^{17}$ In 1994 , state courts in the U.S. convicted 870,000 people of a felony, and the federal courts another 44,000. Given the conviction rates cited earlier, prosecutors must have brought felony charges against slightly more than 1 million defendants. If we use the FBI's definition of "serious crime" arrests as a rough (albeit

${ }^{14}$ There is, of course, a tradeoff between ease of prosecution and seriousness of the offense. The prosecutor who just wants to win will not prosecute murders (which elicit heavy spending on defense) or fraud (which has complicated elements of proof). Even prosecutors who focus on the most serious crimes, however, will tend to start with the easiest cases in each class and move to harder ones as budget and time permit.

15 Take the special independent prosecutors in the U.S. With enormous budgets, they prosecute people who may be guilty, but are far less obviously guilty than the typical defendant tried on burglary or auto theft charges.

16 The calculations that follow rely on the following sources. On the U.S., see U.S. Dept. of Commerce, ed., Statistical Abstract of the United States tabs. 323, 333 (Washington, D.C.: U.S. Department of Commerce, 1996); U.S. Dept. of Justice, Bulletin - Prosecutors in State Courts, 1994 (1996, NCJ - 151656). On Japan, see Yasuo Watanabe, Setsuo Miyazawa, Shigeo Kisa, Shosaburo Yoshino \& Tetsu Sato, Tekisuto bukku gendai shiho [Textbook: The Modern Judiciary] 110 (Tokyo: Nihon hyoron sha, 3d ed., 1997); Homusho, ed., Hanzai hakusho [White Paper on Crime] 402-03, 411-13, 430-31 (Tokyo: Okura sho, 1996). The resource shortage in Japan is rightly noted in John Owen Haley, Authority Without Power: Law and the Japanese Paradox ch. 6 (New York: Oxford University Press, 1991).

17 The clearance rate discussion is based on: Homusho, supra note 16, at 432; U.S. Dept. of Commerce, supra note 16, at tabs. 316, 323; U.S. Dept. of Justice, supra note 1 and supra note 5. 
obviously imperfect) proxy for felony arrests, we obtain a 42 percent prosecution/arrest ratio in felony cases. ${ }^{18}$ In Japan, by contrast, against the 919,000 people arrested for Criminal Code violations in 1995, prosecutors filed charges against a scant 17.5 percent.

To avoid the potential problems raised by mismatched statistical categories, focus on murders. In 1994, U.S. police arrested 19,000 people for roughly 26,000 murders. Courts convicted 12,000. Again using conviction rates to infer prosecutions from convictions, we can deduce that prosecutors prosecuted roughly 75 percent of all people arrested on murder charges. In Japan, of the 1,822 people arrested for murder, prosecutors tried only 43 percent. ${ }^{19}$

\section{A Model:}

A formal model can more clearly show how a prosecutor's conviction rates may fall as his resources increase. Let us denote the prosecutor's budget by $B$, the fixed cost of each case prosecuted by $F$ (which we will assume is the same for each case), and the variable cost by $e$. The probability of conviction is $\mathrm{P}(\mathrm{e})$, where $P^{\prime}>0, P \in[0,1)$, and $P(\infty)<1$. Let us also assume that $\mathrm{P}^{\prime \prime}$ $<0$, so there are decreasing returns to effort in any one case. Figure 2 shows how $\mathrm{P}$ might vary with e.

${ }^{18}$ Similar calculations yield prosecution/arrest ratios in the U.S. of: drug trafficking - .6; robbery - .45; burglary - .44; and aggravated assault - .16.

${ }^{19}$ In about two-thirds of the murder cases dropped, according to the official Ministry of Justice white paper, prosecutors simply lacked adequate suspicion against the person arrested. That is just another way of saying that the prosecutors tried the strongest cases first and ran out of time before they got to the rest. Homusho, supra note 16, at 260 (1995 data). 


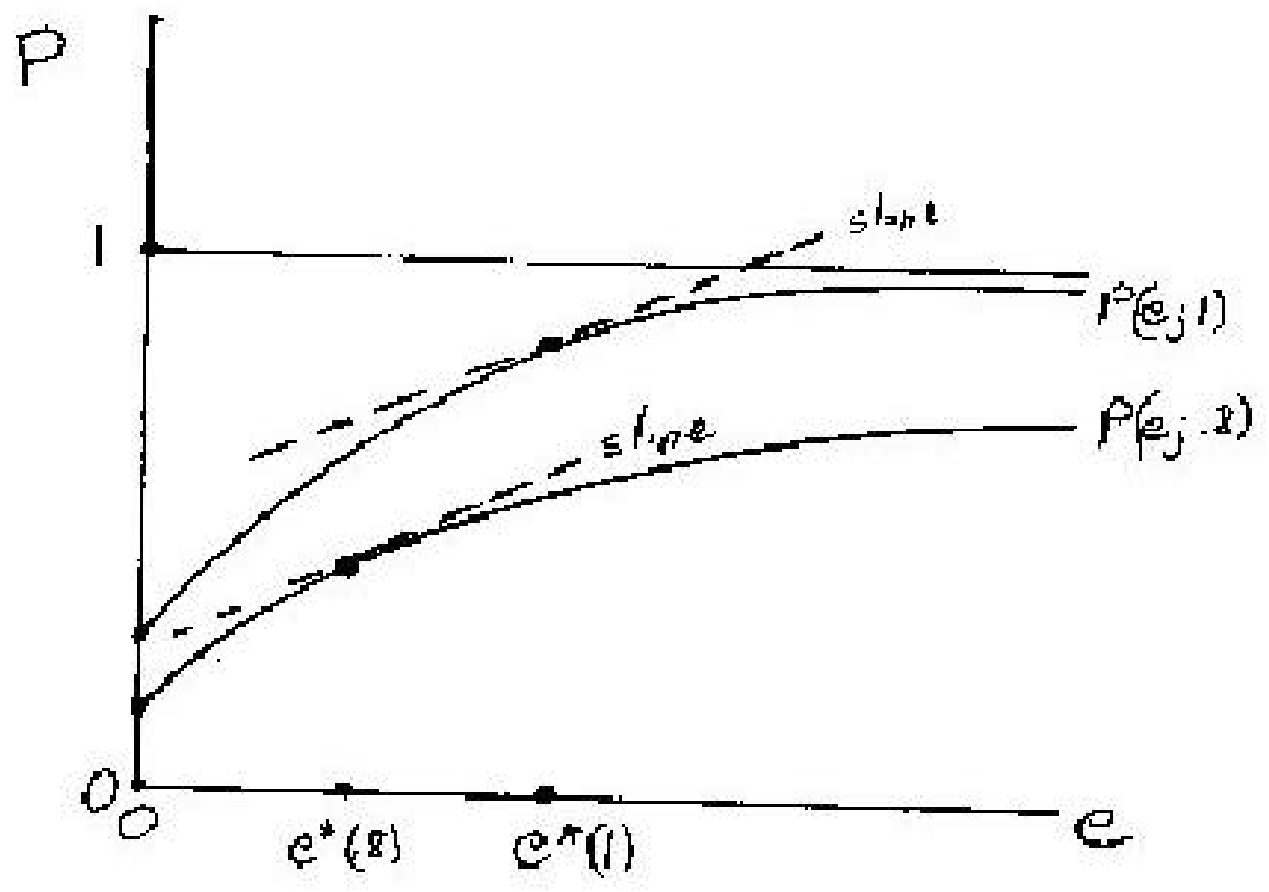

Figure 2: How the Probability of Conviction Varies with Prosecutorial Effort and Case Type

Let us assume that the cost of any one case is trivial compared to the entire prosecutorial budget, so that we can model cases as points on a continuum. Potential cases will be indexed by $\theta$, where $\theta$ varies from 0 to 1 in order of increasing ease of prosecution, so that the universe of possible cases has size 1 . If the prosecutor decides to prosecute the easiest $1 / 3$ of cases, he takes all the cases in the interval $[2 / 3,1] .^{20}$

Suppose the prosecutor spends amount $e(\theta)$ on case $\theta$. A case of type $\theta$ will then have a prosecution success function of ${ }^{21}$

$$
\text { Probability of success }=P(e(\theta) ; \theta) \text {, }
$$

where $\mathrm{P}^{\prime} \geq 0, \mathrm{P}^{\prime}, \leq 0, d \mathrm{P} / \mathrm{d} \theta \geq 0$ and $\mathrm{dP}^{2} / \mathrm{d} \theta^{2} \geq 0$. This says that the probability of a conviction for a case of a given type increases with prosecutorial effort, subject to diminishing returns, but we also allow for cases where extra effort is unproductive $\left(\mathrm{P}^{\prime}=0\right)$ or there are neither increasing nor

${ }^{20}$ This set-up imposes a uniform distribution on the types of cases, but that is not truly a restriction here. Under our assumptions, it is possible that $\mathrm{P}(\mathrm{e})$ does not change when $\theta$ increases (indeed, it could be that all types of cases are identical). A situation where there are many cases with a given ease of prosecution is thus represented here not as a bigger density, but as an interval in which $\mathrm{dP} / \mathrm{d} \theta=0$.

${ }^{21}$ We will use the notation $\mathrm{P}$ ' for the first derivative of $\mathrm{P}$ with respect to e for a given $\theta$. 
diminishing returns $\left(\mathrm{P}^{\prime \prime}=0\right)$. If two cases have equal expenditure, the easier case (with higher $\theta$ ) has at least as great a chance of success, and perhaps a greater one, and also has at least as great a marginal benefit of effort. ${ }^{22}$

An example of such a function is

$$
P(e(\theta) ; \theta)=\theta \quad\left(1-\frac{1}{1+e}\right)
$$

for which

$$
\mathrm{P}^{\prime}=\frac{\theta}{(1+e)^{2}}{ }^{\prime} \mathrm{P}^{\prime \prime}=\frac{-2 \theta}{(1+e)^{3}}, \quad \mathrm{dP} / \mathrm{d} \theta=1-\frac{1}{(1+e)}, \quad \mathrm{dP}^{2} / \mathrm{d}^{2}=0
$$

We now come to the prosecutor's problem. He has two kinds of choices. First, he must decide which cases to prosecute. He will want to prosecute the easier cases first, which amounts to choosing a lower cutoff $\bar{\theta}$ for the interval of types $[\bar{\theta}, 1]$ that he prosecutes. Second, he needs to pick the $e(\theta)$ function which determines how much he spends on each type $\theta$ of case. If the prosecutor chooses to equalize the marginal product of effort in two cases with $\theta=.8$ and $\theta=1$, as in Figure 2, then he would choose $e(.8)$ and $e(1)$ to equalize the slopes of the $P(e ; \theta)$ functions, which means that $e(1)>e(.8)$. Figure 3 shows one $\mathrm{e}(\theta)$ function he might pick, and the two dimensions in which he can change it -- reducing the cutoff (horizontal) and increasing spending on existing cases (vertical).

${ }^{22}$ These assumptions are plausible, but not invariably true. It might be, for example, that the prosecutor can secure a high probability of conviction in a certain case with very little effort, but that further effort is useless, whereas a different case requires more effort in general but has higher marginal product of effort too. Our assumptions rule out that kind of situation, in which the term "easier case" becomes highly ambiguous. 


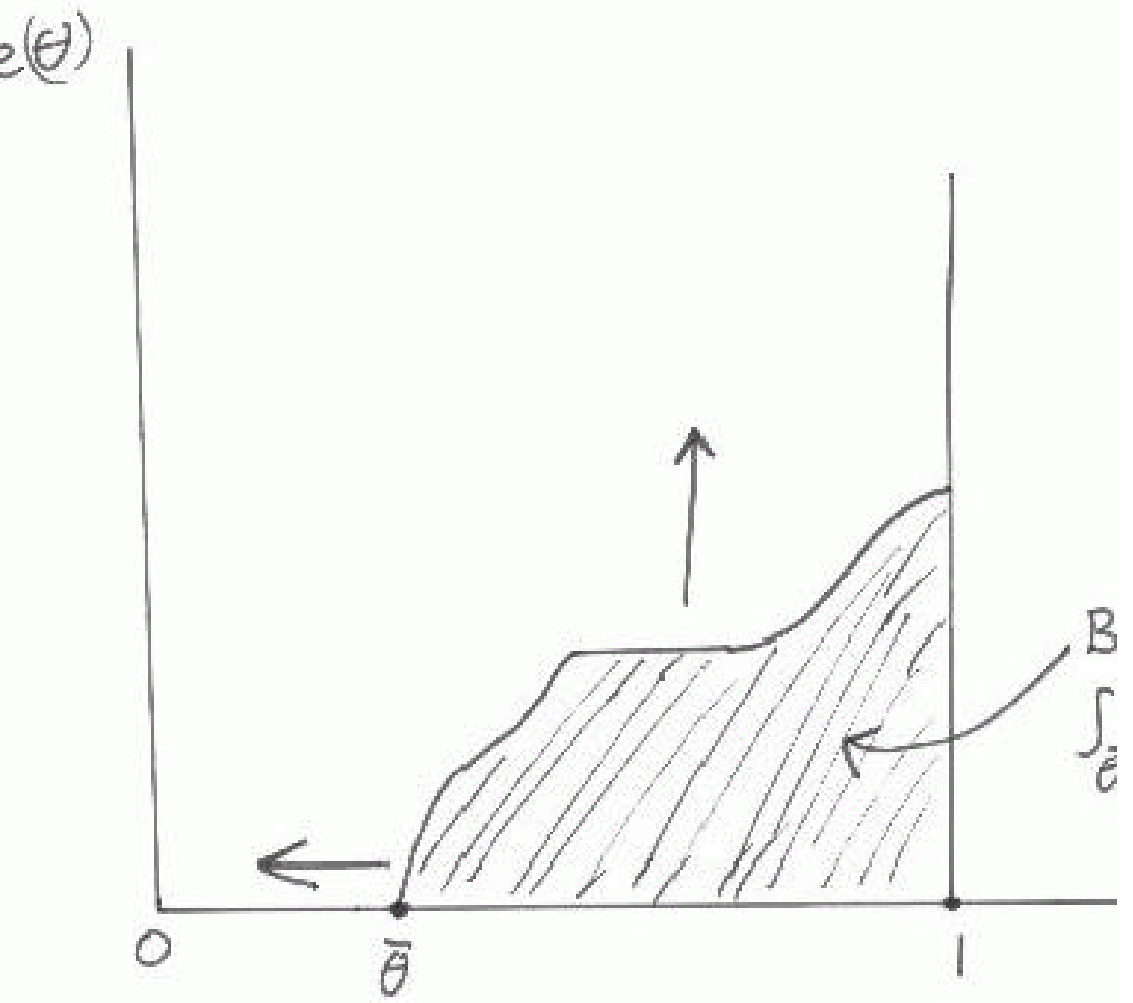

Figure 3: The Prosecutor's Effort as a Function of Case Type

The payoff function for the prosecutor is

(2) $\int_{\frac{1}{\theta}}^{1} \mathrm{P}(\mathrm{e}(\boldsymbol{\theta}) ; \theta) \mathrm{d} \theta$.

The budget constraint is

(3) $\quad \int_{\frac{1}{\theta}}^{1}[e(\theta)+F] d \theta \leq B$.

Note that the shaded area in Figure 3 represents the first part of this integral, the variable costs of prosecution.

The Lagrangian for the prosecutor's optimization problem is

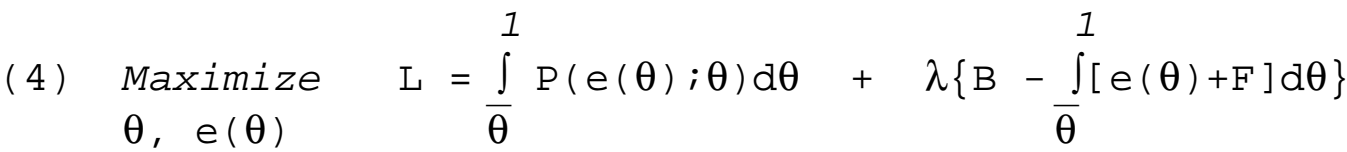


Japanese Conviction Rates: Page 12

Note that 
(5)

$$
\frac{\mathrm{d} L}{\mathrm{~d} B}=\lambda,
$$

which is to say that $\lambda$ equals the marginal value of relaxing the budget constraint.

The problem has two kinds of first-order conditions. First, there is choice of the e $(\theta)$ function, which yields

$$
\mathrm{dL} / \mathrm{de}=\mathrm{P}^{\prime}-\lambda \star(1)=0
$$

Rearranging, we see that the marginal product of effort must be the same for each case prosecuted. For any $\theta$ of a case that is prosecuted, equation (6) gives rise to a condition for the optimal intensive margin of prosecution,

$$
\mathrm{P}^{\prime}(\theta)=\lambda
$$

The second condition concerns the choice of $\bar{\theta}$. It says that

$$
\mathrm{dL} / \mathrm{d} \overline{\boldsymbol{\theta}}=-\mathrm{P}(\mathrm{e}(\overline{\boldsymbol{\theta}}) ; \overline{\boldsymbol{\theta}})--\lambda[\mathrm{e}(\overline{\boldsymbol{\theta}})+\mathrm{F}]=0 \text {. }
$$

This implies that

$$
\frac{P(e(\bar{\theta}))}{e(\bar{\theta})+F}=\lambda,
$$

which, combined with (7), gives us a condition for the optimal extensive margin of prosecution,

$$
\frac{P(e(\bar{\theta}))}{e(\bar{\theta})+F} \quad=P^{\prime}(\theta)
$$

where $\theta$ can take any value of a prosecuted case, not just $\bar{\theta}$. In words, condition (10) says that the marginal product of labor for any case prosecuted must equal the average product of labor for the marginal case.

The variable of most interest for us is the average probability of conviction for the cases the prosecutor selects,

$$
\operatorname{AVG}=\frac{\frac{\int^{1}}{\theta} \mathrm{P}(\mathrm{e}(\theta)) \mathrm{d} \theta}{1-\bar{\theta}} .
$$

Three things affect whether increasing the budget, $B$, leads to a rise or a fall in the average probability of conviction: the fixed cost F, the rate at which returns to effort diminish $\mathrm{P}$ ', and the variability in ease of prosecution $\mathrm{dP} / \mathrm{d} \theta$.

First, how big is the fixed cost $F$ ? If it is big, then the extra budget would best go to existing cases, and the average conviction rate will rise. Or, if $F$ is very small, then the prosecutor will 
prosecute all cases -- another corner solution -- and an increase in the budget will increase the average probability of success for sure. Thus, $\mathrm{dAVG} / \mathrm{dB}>0$ for large values of $\mathrm{F}$.

Second, how rapidly do returns to effort diminish -- is $P^{\prime \prime}$ large in magnitude, indicating sharply diminishing returns? If instead $\mathrm{P}^{\prime \prime}$ is small, then the marginal return to effort $\mathrm{P}^{\prime}$ does not change much as effort increases. That in turn implies that as the budget increases, existing cases continue to provide almost as much "bang for the buck" as they did before. Accordingly, the increased spending will go to those existing cases. The marginal case ( $\bar{\theta}$ in equation (11)) will not change much, while e increases, so AVG will increase.

On the other hand, if $P^{\prime \prime}$ is very large, there are sharply diminishing returns to spending on existing cases. If new budget dollars went to old cases, $\mathrm{P}^{\prime}$ would fall sharply to the point where the marginal product would be well below the average product on new cases. Therefore, more of the new budget will go to new cases. In turn, the identity of the marginal case $\bar{\theta}$ will decline and AVG will decline with it in equation (11). Thus, $\mathrm{dAVG} / \mathrm{dB}<0$ for large magnitudes of $P^{\prime \prime}$.

Third, it matters how rapidly the quality of cases declines, which is captured by the value of $\mathrm{dP} / \mathrm{d} \theta$. If $\mathrm{dP} / \mathrm{d} \theta$ is large, then as the prosecutor selects better cases his probabilities of conviction rise dramatically. Correspondingly, dipping deeper into the case pool will reduce his success rate. This means that the prosecutor will be reluctant to add new cases as his budget increases, and will use more of the extra money to improve his chances in the old cases. Thus, $\mathrm{dAVG} / \mathrm{dB}>0$ for large magnitudes of $\mathrm{dP} / \mathrm{d} \theta$.

Consider two extreme cases that illustrate these three considerations.

Situation Alpha. Let all cases be identical in their $\mathrm{P}(\mathrm{e})$ functions, so $\mathrm{dP} / \mathrm{d} \theta=0$, with the fixed cost $\mathrm{F}$ low relative to the budget B. All cases are taken. Additional budget B leads to increased spending on existing cases, and higher average success.

Situation Beta. Let all cases be identical in their $\mathrm{P}(\mathrm{e})$ functions, so $\mathrm{dP} / \mathrm{d} \theta=0$, with the fixed cost $\mathrm{F}$ high. The marginal benefit of effort per case falls sharply, so $\mathrm{P}^{\prime \prime}$ is very negative. Then, additional budget $\mathrm{B}$ will lead to more cases, and a lower average success.

We suggest that Japan is more like Situation Beta. If a prosecutor were to be given a greater budget, he would spend it on prosecuting more cases, not in prosecuting his existing cases more intensely. What of the intuition that a prosecutor with a bigger budget will invest more in the cases he has already accepted, raising his aggregate conviction rate? Our argument to the contrary hinges on two assumptions.

First, we assume that a prosecutor will not file a case unless he can invest enough resources in it to make a plausible showing of guilt. We believe that this assumption is reasonable, if only because of a concern by prosecutors for their reputations and for avoiding irritating judges with sloppy work.

Second, we assume that the first investments a prosecutor makes in a case earn very high returns, quickly raising the expected conviction rate from near zero to a comfortable probability, but that effort runs into sharply diminishing marginal returns after the initial investment. We find this assumption particularly plausible for a bench-trial jurisdiction such as Japan. After investing enough effort in a case to make the basic showing, the U.S. prosecutor devotes much of the rest of his time to such tasks as voi dire in jury selection or showmanship before the jury. By contrast, Japanese prosecutors argue before professional judges. It is important for the prosecutor to present the facts and the law, but how he presents them -- a task with enormous potential for polishing and artistry -is much less important. That initial investment in presenting the facts, however, is all the more 
important, since before a jury a small investment in dramatic performance can sometimes cure a sloppy case.

What of the well-known Priest-Klein hypothesis that because of settlement and plea bargaining, litigated verdict rates do not reflect the distribution of liability or guilt in the underlying population of cases ? $^{23}$ The point is simply irrelevant to our discussion. The effect of prosecutorial poverty in Japan is to remove the credibility from the prosecutor's threats to try hard cases. If the threat is not credible, then only the obviously guilty will plead guilty. Accordingly, the prosecutor's small budget will cause both the plea-bargained and the contested cases to be disproportionately selected from defendants who are clearly guilty. The rest of the cases will be neither settled, nor tried, but simply dropped.

Nor does it matter whether the average success rate at trial AVG enters directly into the prosecutor's utility function as a separate argument from the expected number of convictions. This is plausible. American prosecutors like to boast about the percentage of their cases that result in convictions. When praising the U.S. Justice Department in confirmation hearings, for example, Senator Leahy declared: ${ }^{24}$

The Attorney General's most recent annual report reflects just what a good job the Department has been doing: federal prosecutors around the country conducted more than 23,000 grand juries and filed more than 38,000 indictments against more than 58,000 defendants. The report indicates an overall conviction rate of 87 percent. That is impressive and a real testament to the many dedicated career investigators, prosecutors and support personnel who enforce the laws with consummate professionalism. It also is a real testament to the top career officials in the Criminal Division...

In a typical press release for a local prosecutor's race, we read: ${ }^{25}$

Attorney Thomas Broderick Jr. will formally announce Tuesday that he is a candidate for the Democratic nomination for Madison County prosecutor. ... He was chief deputy for Prosecutor William F. Lawler Jr. for more than seven years, claiming a 98 percent personal conviction rate on cases ranging from drugs to murder.

Senator Leahy's statement explicitly praises both the number of successes and the percentage of conictions; Mr. Broderick's mentions only the percentage, but even he would be in trouble if he prosecuted too few cases.

That the percentage enters directly, however, would not eliminate the effects of budget increases that we have described. In allocating a budget of any size, a prosecutor would slant his allocation towards improving his percentage won, but if given an extra yen, he would split it between his two objectives of improving his percentage and improving his number of cases won -and increasing the number of cases would be a better use of the money under the extreme cases we have described above (e.g. $\mathrm{P}^{\prime \prime}$ very negative) even if it lowers his conviction rate.

An interesting implication of this more complicated utility function is that local prosecutors (who tend to be elected) may have higher conviction rates than federal prosecutors (who are appointed). The U.S. data presented earlier in this paper are consistent with this. Another implication is that criminal conviction rates should be much higher than civil plaintiff victory rates --

${ }^{23}$ George L. Priest \& Benjamin Klein, The Selection of Disputes for Litigation, 13 J. Legal Stud. 1 (1984).

${ }^{24}$ Prepared Statement of Senator Patrick Leahy, Ranking Member, Before the Senate Judiciary Committee Hearing on the Nomination of James K. Robinson to be Assistant Attorney General for the Criminal Division (Federal News Service, April 22, 1998).

${ }^{25}$ Attorney says he'll be candidate for prosecutor, The Indianapolis Star, January 17, 1998, at N02. 
also something very true, and otherwise mysterious. The reason for different verdict rates in civil and criminal trials has nothing to do with jury unanimity requirements or burdens of proof. Such requirements will not affect the percentage of trials that end in convictions, since prosecutors will take them into account in deciding whether to pursue a case. Rather, criminal conviction rates are higher than civil plaintiff win rates because prosecutors have more reason than plaintiffs to avoid losing at trial.

\section{Empirics:}

A. Introduction:

If prosecutors in Japan prosecute a higher percentage of guilty defendants than in the U.S., higher conviction rates will result under unbiased adjudication. In Section III, we ask whether the Japanese judicial bureaucracy does reward unbiased accuracy, or instead rewards convictions. We first outline the general bureaucratic organization of the courts (Section B). We then explain our test, our data, and the variables involved (Section C), and turn to our results (Section D).

\section{B. The Judicial Bureaucracy: \\ 1. Typical careers. $^{26}$}

A would-be judge in Japan begins his legal education while still a college undergraduate. There, he majors in law. During his last year, he takes the entrance exam for the one national law school, the Legal Research \& Training Institute (LRTI). If extraordinarily skilled or lucky, he passes it on his first try. More likely, he takes it once every year until he passes it four or five years later or despairs and chooses another vocation.

Students stay at the LRTI for two years. There, they attend lectures on legal practice and serve clinical assignments at various private and public offices. Toward the end of their stay, they select a career. Most will become lawyers in private practice. The rest will become judges or prosecutors.

Formally, the Cabinet chooses the judges to appoint, but usually it defers to the Supreme Court Secretariat, the administrative office of the courts. When the new judges join the court, the Secretariat will name them to specific courts. The Secretariat itself is staffed by career judges, and a posting there at some point during a judge's career signals recognized talent. By law, all judges serve a succession of 10-year terms. In practice, the Cabinet generally reappoints them until they retire in their early 60's. All judges face mandatory retirement at age 65.

The Japanese government maintains eight high courts and a widely dispersed array of district and family courts. Virtually all of the judges (about 2,800 in total) are part of the career judiciary. Some of the courts also maintain branch offices in smaller cities. Like most Japanese professionals, judges generally prefer to work in Tokyo or one of the larger metropolitan areas. Almost uniformly, they consider branch office assignments the worst posts in the system.

The Secretariat regularly moves judges around the country and up and down the judicial hierarchy. Some cities are more attractive than others, and some responsibilities more prestigious. As a result, by controlling these periodic assignments (usually made at 3-year intervals), it can

${ }^{26}$ Fuller discussions of the material in this summary, together with citation to the relevant statutes when appropriate, appear in J. Mark Ramseyer \& Eric B. Rasmusen, Judicial Independence in a Civil Law Regime: The Evidence from Japan, 13 J. Law, Econ. \& Org 259 (1997), and in J. M. Ramseyer \& F. M. Rosenbluth, Japan's Political Marketplace chs. 8-9 (Cambridge: Harvard University Press, 1993). 
reward and punish judges. Also, although it cannot lower a judge's salary, it can vary the pace at which it promotes judges up the salary scale.

For any given judge, the earliest signs of talent are graduation from a selective university and admission to the LRTI within a very few years of graduation (the latter indicates he passed the entrance examination on one of his first tries). Generally, the most talented judges begin at the Tokyo District Court. During their career, they will rotate out of Tokyo and serve some time in less desirable posts. In general, however, they will stay on a faster track than their less talented peers. As part of this faster track, they will spend more time in desirable locations, less time in branch offices, and more time with important administrative responsibilities.

Only the Supreme Court stands apart from this system. The Cabinet and Prime Minister appoint Supreme Court justices to serve until mandatory retirement at age 70 . The justices are not subject to 10-year terms or to reassignment by the Secretariat. Nominally, voters can remove them at any national election; in fact, voters never have. Supreme Court justices typically take the job in their early 60's. A plurality of them have served as career lower-court judges before their appointment, but, as in the U.S. system, appointment to the Supreme Court depends not just on talent but also on considerable luck.

The Supreme Court contains 15 justices, one of which is the Chief Justice. The Chief Justice also serves as the administrative head of the entire lower-court system. In that capacity, he supervises the head of the Secretariat. Usually, at least one of the justices headed the Secretariat shortly before joining the Supreme Court.

\section{Manipulation. ${ }^{27}$}

In several contexts, the Secretariat has indeed manipulated job assignments to reward and punish judges either for their politics or for the complexion of the opinions they write. In the 1960s, for example, many young judges joined the Young Jurists League (YJL) -- a left-wing organization analogous to the National Lawyers Guild. Under pressure from the government (controlled by the conservative Liberal Democratic Party [LDP]), the Secretariat instructed those judges to resign their membership. Most did. Come the 1980s, however, those who had once been members were still receiving less attractive posts than their peers.

Similarly, consider the statutory ban on door-to-door canvassing. Like most other restraints on electioneering, the ban helps incumbents and hurts challengers. Because the LDP had many incumbents where the Communist Party had few, the ban helped the LDP and hurt the Communists. Although the Supreme Court had long held the ban constitutional, when Communist candidates challenged it some lower court judges struck it down. When they did, their careers suffered. Were they punished for bad politics, or rather for ignoring precedent? For our purposes here, the answer does not matter. ${ }^{28}$ What does matter is that the Secretariat can and will discipline judges for the opinions they write.

C. The Data

$$
\text { 1. The test. }
$$

${ }^{27}$ These accounts are detailed in Ramseyer \& Rasmusen, supra note 26, at 283-5. For other anecdotes, see Ramseyer \& Rosenbluth, supra note 26, at chs. 8-9; J. Mark Ramseyer, The Puzzling (In)dependence of Courts: A Comparative Approach, 23 J. Legal Stud. 721 (1994). For a different interpretation, see John O. Haley, Judicial Independence in Japan Revisited, 25 Law in Japan 1 (1995).

${ }^{28}$ Though it is a question we plan to explore in further research. 
In exploring whether Japanese judges face biased incentives to convict, the gist of our test is simple. We took all 455 district court criminal case opinions published in 1976 or 1979 (our reference years), and identified the deciding judges. We chose years in the late 1970s because we need 10 years of post-decision judicial career data and at the time we collected our data our information on judicial careers ran only to 1991. We chose 1976 and 1979 rather than two adjacent years because doing so generated a larger sample (321 judges). Recall that the Secretariat generally reassigns judges every three years. Because judges sometimes specialize by subject matter during a given a 3-year assignment, by choosing years three years apart we could collect data on two almost entirely different judicial cohorts. ${ }^{29}$

We divided our judges into two groups according to whether they acquitted a defendant in one of the reference years. We further divided those who acquitted a defendant into those who did so as part of a three-judge panel and those who did so as a single judge. Concurrently, we also divided all judges who had a case appealed according to whether the appeal resulted in a reversal or an affirmance.

For each of our judges, we measured the attractiveness of the jobs he held during the 10 years after the relevant reference year. Holding constant a variety of factors found pertinent in related research (primarily seniority, and several proxies for ideology, effort, and intelligence), we then tested whether an acquittal led to a worse job posting.

Note that if we do find a worse job posting, that still does not disclose the Secretariat's motive. On the one hand, we suspect it is trying to give judges incentives to act as it wishes. Judges in Japan probably do not have high incomes as their first priority, since most could earn more in the private sector. They probably do, however, value prestige, a job in a city where their children can obtain a good education, proximity to the center of intellectual life, and judicial influence. Indeed, if they care less about money than their peers, they presumably care about these other things more -and a posting to a branch office hurts in all these ways.

Even if judges ignored such incentives, though, the Secretariat would still have reason place troublesome judges in branch offices. It would do so simply to remove them from positions of influence. Given the differential location of case filings, in branch offices those judges would have have less opportunity to make important rulings. Given the smaller number of colleagues there, they would also have less chance to persuade other judges to share their views.

2. The data.

${ }^{29}$ We dropped those cases that did not give the name of the deciding judge (14 convictions, 6 acquittals), those cases whose outcome was hard to code (11 cases), and those judges who did not appear in our career records (they were probably prosecutors seconded to the courts - an occasional practice). In addition, we dropped those judges who had been appointed less than a year before the reference year, and those who quit less than two years after the reference year (about 20 judges). With the 2 judges for whom we lacked the information on FLUNK, we used the sample-wide mean.

We also examined the high court opinions in 1976 and 1979 and traced back the judges who wrote the district court opinions. Perhaps because of the wider variation in years written, however, the results are more haphazard and inconclusive. We thus limit ourselves to the more uniform sample of district court opinions written in 1976 or 1979. 
We obtained records of published opinions from the Hanrei taikei database. ${ }^{30}$ The database is functionally equivalent to Lexis and Westlaw, and is available on 9 or 10 (depending on the year) CD-ROMs. It covers nearly all the Japanese public and private case reporters.

We obtained the records of judicial careers from the Zen saibankan keireki soran. ${ }^{31}$ The book, published in 1990, includes every judicial post held by every judge educated since World War II.

We located membership in the YJL (the leftist legal organization mentioned earlier) in Osorubeki saiban. ${ }^{32}$ A right-wing group published this book to attack what it saw as the increasingly leftist tendencies in the courts. In it, the group included the 1969 YJL membership roster, which it took from the YJL's own newsletter.

\section{The variables.}

We use the sources just discussed to construct the following variables. They fall into three general categories: variables measuring job quality; control variables indirectly measuring effort, intelligence, or ideology (or some combination of the three); and variables related to published opinions. Summary statistics appear in Table 1.

a. Job quality.

PREGOODJOB: The percentage of time during the 10 years preceding the reference year, in which a judge had a high status appointment: primarily, the time he held sokatsu responsibilities (a modestly prestigious position), worked in the Secretariat or the Ministry of Justice, or served as a Chief Judge.

POSTGOODJOB: Analogous to PREGOODJOB for the 10 years after the reference year.

PREBADJOB: The percentage of time during the 10 years preceding the reference year, in which a judge served in a branch office (we exclude appointments to the branch office in Hachioji in suburban Tokyo; we include appointments to summary courts) -- a low status appointment.

POSTBADJOB: Analogous to PREBADJOB for the 10 years after the reference year.

As explained below, we use POSTGOODJOB and POSTBADJOB as our dependent variables. Because the Secretariat tends to track judges onto relatively faster and slower tracks, in general PREGOODJOB should be positively correlated with POSTGOODJOB, and PREBADJOB with POSTBADJOB.

b. Control variables.

SENIORITY: The number of years since the judge graduated from the LRTI.

FLUNK: The estimated number of years (using the judge's birth year) between a judge's graduation from university and his entrance to the LRTI. Because the LRTI had an entrance exam with a pass rate between 1 and 4 percent during this period, most people passed it only after failing several times first. As a result, FLUNK approximates the number of times the judge failed the LRTI entrance exam, and will correlate inversely with demonstrated ability.

${ }^{30}$ Daiichi hoki shuppan, K.K., ed., Hanrei taikei CD-ROM [A Systematic Case Law: CD-ROM] (Tokyo: Daiichi hoki, biannually updated).

${ }^{31}$ Nihon minshu horitsuka kyokai, ed., Zen saibankan keireki soran: kaitei shinban [Biographical Information on All Judges: New Revised Edition] (Tokyo Konin sha, 1990). The third edition has since (in 1998) been published.

${ }^{32}$ Shiho undo kenkyujo, ed., Osorubeki saiban [Fearsome Trials] (Tokyo: Zenbo sha, 1969). 
ELITEU: 1 if a judge graduated from either of the two most prestigious universities, the University of Tokyo and the University of Kyoto, 0 otherwise.

$\mathbf{1}^{\text {ST }}$-TOK: 1 if a judge's first assignment was in a Tokyo court, 0 otherwise. In general, the Secretariat identifies the most promising young judges at the time it hires them, and for their first job assigns them to the Tokyo District Court.

OPINIONS/YR: The number of published opinions solely or jointly authored by a judge during the ten years preceding the reference year, divided by the number of years the judge was on the bench during that time (we exclude years when a judge held an administrative post that precluded writing opinions). This is an indicator of how hard a judge worked and how newsworthy the judicial reporters (some of which are official government publications, and some of which are private) considered his opinions to be.

YJL: Membership in the YJL in 1969: 1 if a member, 0 otherwise.

Each of these variables will plausibly influence the careers of the judges in our sample. According to our 1997 study, ${ }^{33}$ FLUNK and YJL are negatively correlated with career success; SENIORITY, $1^{\text {ST }}$-TOK, and OPINIONS/YR are positively correlated with career success; and ELITEU is positively correlated with at least an attractive initial job (i.e., with $1^{\text {ST }}$-TOK).

c. Published opinions.

ANYACQ: 1 if a judge participated in an opinion acquitting a defendant (or accepting part of a defendant's argument), 0 otherwise.

SOLOACQ: The same as ANYACQ, but excluding acquittals by 3-judge panels.

ACQ-REV: 1 if a judge participated in an opinion acquitting a defendant (as defined above) that was reversed by a High Court (or where the High Court increased the penalty on appeal), 0 otherwise. $^{34}$

ACQ-AFF: 1 if a judge participated in an opinion acquitting a defendant that was affirmed by a High Court, 0 otherwise.

CON-REV: 1 if a judge participated in an opinion convicting a defendant (or rejecting all of the defendant's claims) that was reversed by a High Court (or where the High Court reduced the penalty on appeal), 0 otherwise.

CON-AFF: 1 if a judge participated in an opinion convicting a defendant that was affirmed by a High Court and did not participate in any of ACQ-REV, ACQ-AFF, or CON-REV, 0 otherwise.

\footnotetext{
${ }^{33}$ Ramseyer \& Rasmusen, supra note 26.

${ }^{34}$ Japanese courts do not consider this double jeopardy.
} 
Table 1: Sample Statistics

\begin{tabular}{lllll} 
& Minimum & Median & Mean & Maximum \\
\hline PREGOODJOB & 0 & 0 & .078 & .970 \\
POSTGOODJOB & 0 & .27 & .341 & 1 \\
PREBADJOB & 0 & .20 & .204 & 1 \\
POSTBADJOB & 0 & .20 & .234 & 1 \\
\hline SENIORITY & 2 & 13 & 13.5 & 29 \\
FLUNK & 0 & 3 & 4.22 & 17 \\
ELITEU & 0 & 0 & .321 & 1 \\
$1^{\text {ST-TOK }}$ & 0 & 0 & .112 & 1 \\
OPINIONS/YR & 0 & .85 & 1.34 & 14.11 \\
YJL & 0 & 0 & .109 & 1 \\
\hline ANYACQ & 0 & 0 & .271 & 1 \\
SOLOACQ & 0 & 0 & .053 & 1 \\
ACQ-REV & 0 & 0 & .034 & 1 \\
ACQ-AFF & 0 & 0 & .040 & 1 \\
CON-REV & 0 & 0 & .050 & 1 \\
CON-AFF & 0 & 0 & .150 & 1 \\
\hline
\end{tabular}

n: 321

\section{The Results:}

1. Introduction.

In Table 2, we report the results of two sets of regressions. The set displayed in columns 2.1 and 2.2 uses ANYACQ as the key explanatory variable. The set displayed in columns 2.3 and 2.4 uses SOLOACQ as the key explanatory variable. Within each set, the first column shows the regressions with POSTGOODJOB as the dependent variable, and the second with POSTBADJOB. Within each column, we first show the coefficients, and display the absolute value of the t-statistics below them in parentheses. We have used the conventional two-sided t-tests throughout this article, even though arguments could be made for using one-sided tests in many places (which would be more likely to show coefficients significantly different from zero).

2. Job quality.

The job quality variables show that the Secretariat does seem to track judges into faster and slower career trajectories. PREGOODJOB is positively correlated with POSTGOODJOB, though it does not quite reach statistical signifance, and PREBADJOB is significantly correlated with POSTBADJOB. Those judges who spend more time with prestigious administrative responsibilities in the 1970s spent more time with such responsibilities in the 1980s. Those who spent more time in branch offices in the 1970s spent still more time in branch offices in the 1980s. 


\section{Control variables.}

The variables proxying for effort, intelligence, and ideology also have most of the predicted effects. First, SENIORITY is positively and significantly correlated with POSTGOODJOB, and negatively and significantly correlated with POSTBADJOB. The more senior the judge, the more time he spends with administrative responsibilities and the less time in branch offices.

Second, the fewer the times a judge failed the LRTI entrance exam, the more time he spent with administrative responsibilities. FLUNK is negatively and significantly correlated with POSTGOODJOB.

Third, judges who began their careers at the Tokyo District court spent less time in branch offices in the 1980s. $1^{\mathrm{ST}}$-TOK is negatively and significantly correlated with POSTBADJOB. The Secretariat begins its career tracking at the very outset, in other words, and those judges it identifies as most promising at the start continue to receive the best jobs several decades later.

Last, leftist judges suffered. YJL is positively and significantly correlated with POSTBADJOB. Those judges affiliated with the left-wing YJL in 1969 were still spending more time in branch offices in the 1980s.

\section{Opinions.}

a. ANYACQ. To test whether Japanese judges face biased career incentives in criminal cases, consider regressions 2.1 and 2.2. Here, we test whether a judge involved in any published opinion acquitting a defendant incurred a career penalty over the next decade.

The results are inconclusive. The coefficient on ANYACQ is positive in the POSTBADJOB regression. With a t-statistic of 1.55 , however, it is significant only at the 12 percent level. In the POSTGOODJOB regressions, the coefficient is not even in the predicted direction. 
Table 2: The Effect of Acquittals on Judicial Careers

\begin{tabular}{|c|c|c|c|c|}
\hline & $(2.1)$ & $(2.2)$ & $(2.3)$ & $(2.4)$ \\
\hline LHS: & POSTGOODJOB & POSTBADJOB & POSTGOODJOB & POSTBADJOB \\
\hline Intercept & $\begin{array}{l}-.501 * \star * \\
(5.47)\end{array}$ & $\begin{array}{l}.342 * \star \star \\
(5.24)\end{array}$ & $\begin{array}{l}-.487 * * \star \\
(5.39)\end{array}$ & $\begin{array}{l}.354 * \star * \\
(5.57)\end{array}$ \\
\hline PREGOODJOB & $\begin{array}{l}.229 \\
(1.50)\end{array}$ & $\begin{array}{c}\text { XXXXXXXXXXXXX } \\
\text { XXXXXXXXXXXXX } \\
X\end{array}$ & $\begin{array}{l}.224 \\
(1.46)\end{array}$ & $\begin{array}{c}\mathrm{XXXXXXXXXXX:} \\
\mathrm{XXXXXXXXXXXX} \\
\mathrm{X}\end{array}$ \\
\hline PREBADJOB & $\begin{array}{l}\text { XXXXXXXXXXXXXX } \\
\text { XXXXXXXXXXXXXX }\end{array}$ & $\begin{array}{l}.329 * * * \\
(2.91)\end{array}$ & $\begin{array}{l}\text { XXXXXXXXXXXXXX } \\
\text { XXXXXXXXXXXXXX }\end{array}$ & $\begin{array}{l}.305 * * * \\
(2.72)\end{array}$ \\
\hline SENIORITY & $\begin{array}{l}.053 * \star * \\
(11.74)\end{array}$ & $\begin{array}{c}-.023 * \star * \\
(6.85)\end{array}$ & $\begin{array}{l}.053 * \star * \\
(11.72)\end{array}$ & $\begin{aligned}-.023 * * * \\
(6.92)\end{aligned}$ \\
\hline FLUNK & $\begin{array}{r}-.018 * \\
(1.93)\end{array}$ & $\begin{array}{l}.005 \\
(0.62)\end{array}$ & $\begin{array}{c}-.017 * \star \\
(1.85)\end{array}$ & $\begin{array}{l}.004 \\
(0.59)\end{array}$ \\
\hline ELITEU & $\begin{array}{l}-.002 \\
(0.04)\end{array}$ & $\begin{array}{l}-.063 \\
(1.18)\end{array}$ & $\begin{array}{l}-.010 \\
(0.16)\end{array}$ & $\begin{array}{l}-.050 \\
(0.96)\end{array}$ \\
\hline $1^{\mathrm{ST}}-\mathrm{TOK}$ & $\begin{array}{c}.138 \\
(1.50)\end{array}$ & $\begin{array}{c}-.151 * \\
(1.90)\end{array}$ & $\begin{array}{l}.071 \\
(1.61)\end{array}$ & $\begin{array}{c}-.168 * * \\
(2.12)\end{array}$ \\
\hline OPINIONS /YR & $\begin{array}{l}.007 \\
(0.38)\end{array}$ & $\begin{array}{l}-.006 \\
(0.39)\end{array}$ & $\begin{array}{l}.007 \\
(0.36)\end{array}$ & $\begin{array}{l}-.004 \\
(0.23)\end{array}$ \\
\hline YJL & $\begin{array}{l}-.042 \\
(0.12)\end{array}$ & $\begin{array}{l}.144 * * \\
(2.00)\end{array}$ & $\begin{array}{l}-.011 \\
(0.13)\end{array}$ & $\begin{array}{l}.142 * * \\
(1.99)\end{array}$ \\
\hline ANYACQ & $\begin{array}{l}.023 \\
(0.66)\end{array}$ & $\begin{array}{l}.081 \\
(1.55)\end{array}$ & $\begin{array}{l}\text { XXXXXXXXXXXXXX } \\
\text { XXXXXXXXXXXXXX }\end{array}$ & $\begin{array}{l}\text { XXXXXXXXXXX: } \\
\text { XXXXXXXXXXX: }\end{array}$ \\
\hline SOLOACQ & $\begin{array}{l}\text { XXXXXXXXXXXX } \\
\text { XXXXXXXXXXXX }\end{array}$ & $\begin{array}{l}\text { XXXXXXXXXXXX } \\
\text { XXXXXXXXXXXX }\end{array}$ & $\begin{array}{l}-.108 \\
(0.82)\end{array}$ & $\begin{array}{l}.224 * * \\
(2.27)\end{array}$ \\
\hline Pseudo $\quad R^{2}$ & .31 & .16 & .31 & .17 \\
\hline $\begin{array}{l}\text { Stan. Error } \\
\# \text { Censored } \\
(y<0, y>1)\end{array}$ & $\begin{array}{c}.44 \\
(132,28)\end{array}$ & $\begin{array}{c}.37 \\
(134,5)\end{array}$ & $\left(132^{44}, 28\right)$ & $\begin{array}{c}.37 \\
(134,5)\end{array}$ \\
\hline
\end{tabular}




\section{Notes:}

Coefficients, followed by the absolute value of the t-statistic in parenthesis on row below.

*** -- significant at more than the 1 percent level.

** -- significant at more than the 5 percent level.

* -- significant at more than the 10 percent level.

The regression uses tobit and there are 321 observations.

b. SOLOACQ. Importantly, the data set includes convictions and acquittals authored both by 3 -judge panels (107 cases) and single judge panels (317). This loosely mirrors the way courts decide criminal cases more generally. Of all cases (published and unpublished) decided in 1994, 3judge panels decided 7.6 percent $\left(3,751\right.$ cases), and single judges decided 92.4 percent $(45,529) .{ }^{35}$

By law, 3-judge panels must decide the most serious criminal cases. ${ }^{36}$ Single judges generally decide the rest. Although the assigning mechanism depends on the local court, commonly a minor incoming criminal case will go directly to a single judge, who will then decide it himself. If it is unusually hard, he will route it to a 3-judge panel.

In general, if prosecutors seldom prosecuted obviously innocent defendants (as suggested in Part II), if judges were fair and unbiased, and if single judges handled the most straightforward cases themselves - if all this were true, then cases decided by single judges would show lower acquittal rates than cases handled by three-judge panels. Preliminarily, the data are consistent with this hypothesis. Among our published opinions, 33 percent of the panel opinions were acquittals, but only 7 percent of the single-judge opinions. Of all 1994 cases published and unpublished, 1.2 percent of all panel opinions were acquittals, but only 0.09 percent of all single-judge opinions. ${ }^{37}$

Yet, one should not be so sanguine. Consider Regressions 2.3 and 2.4, in which we test whether a single judge who acquits a defendant incurs a career penalty. According to Regression 2.4 , a judge who acquits alone does indeed suffer. With a t-statistic of 2.27 , the result is significant at the 2.4 percent level.

Interpreting the size of the coefficient takes a bit more work. The tobit model begins with the equation

$$
s_{i}=x_{i} * b+u_{i}
$$

where $u_{i}$ is normally distributed, but $s_{i}$ is just a score, not what we observe. In our case, $x_{i}$ is the set of explanatory variables for the career of judge $I$, and $s_{i}$ is the Secretariat's evaluation of judge $i$. What we observe is not the $\mathrm{s}_{\mathbf{i}}$, but what is called censored data: ${ }^{38}$

$$
\begin{aligned}
& \mathrm{y}_{i}=0 \text { if } \mathrm{s}_{i}<0 \\
& \mathrm{y}_{i}=1 \text { if } \mathrm{s}_{i}>1
\end{aligned}
$$

${ }^{35}$ Saiko saibansho, supra note 1, at tab. 29.

${ }^{36}$ Saibansho ho [Courts Act], Law no. 59 of 1947, § 26.

${ }^{37}$ Saiko saibansho, supra note 1, tab. 29. The published acquittal rates are higher both (i) because acquittals are generally more newsworthy to commercial case reporters, and (ii) because the unpublished convictions mostly involve uncontested proceedings.

${ }^{38}$ This is different from truncated data. If the data had been truncated, we would not observe many 0 s and 1 's -- for we would not have those observations in our sample at all. 


$$
y_{i}=s_{i} \quad \text { otherwise }
$$

In the present case, $\mathrm{s}_{\mathrm{i}}$ is censored because nobody can spend less than 0 or more than 100 percent of a decade in a branch office. Thus, we only observe $y_{i}$. The set of judges for whom $y_{i}=1$ included some judges who just barely avoided getting out of the branch offices, and some judges so annoying that the Secretariat would have put them in branch offices 200 percent of the decade if that were possible.

We observe $y_{i}=0$ if $x_{i}^{*} b+u_{i}<0$, i.e., if $u_{i}<-x_{i}^{*} b$. The probability of that happening is $F(-$ $x_{i}^{*}$ ). We observe $y_{i}=1$ if $x_{i}^{*} b+u_{i}>1$, i.e., if $u_{i}>1-x_{i}^{*} b$. The probability of that happening is 1$\mathrm{F}\left(1-\mathrm{x}_{i}^{*} \mathrm{~b}\right)$, that is, $1-\operatorname{Prob}\left(\mathrm{u}_{i}<1-\mathrm{x}_{i}^{*} \mathrm{~b}\right)$. We observe $\mathrm{y}_{i}$ equal to some particular value $\mathrm{z}$ between zero and 1 if $x_{i}^{*} b+u_{i}=z$.

All this is preliminary to finding a predicted value for $y_{i}$ given $x_{i}$ and $b$. The predicted value is an expected value, based on the probabilities of $u_{i}$ turning out different ways. That expected value is, using the previous three paragraphs,

$$
F\left(-x_{i} * b\right) *(0)+\left[1-F\left(1-x_{i} \star b\right)\right] *[1]+\int_{-x_{i} \star b}\left[x_{i}{ }^{*} b+u\right] f(u)
$$

du,

which can be simplified to

$$
1-F\left(1-x_{i} * b\right)+\left[F\left(1-x_{i} * b\right)-F\left(-x_{i} * b\right)\right] x_{i} * b+\int^{1-x_{i} * b}
$$
uf $(u) d u$.

$$
-\mathrm{x}_{\mathrm{i}}{ }^{\mathrm{b}} \mathrm{b}
$$

Suppose we set the value of all the right-hand-side variables in Regression 2.2 equal to their median values. The predicted value of POSTBADJOB is then .22 , which equals (with rounding)

$$
0+1-.99+(.99-.37)(.12)+.14
$$

If, however, ANYACQ takes the value of 1, instead of the median value of zero, the predicted value of POSTBADJOB rises to .27 , which equals (with rounding)

$$
0+[1-.98]+[(.98-.30)(.20)+.12]
$$

Overall, an otherwise median judge who has an acquittal spends an average of .5 years extra in branch offices.

We can carry out a similar procedure for Regression 2.4. For a judge with the median values of the variables, the predicted value of POSTBADJOB is .23, which equals (with rounding)

$$
(.38)(0)+[1-.99](1)+[(.99-.38)(.12)+.14] .
$$


If, however, SOLOACQ takes the value of 1 instead of the median value of zero, the predicted value of POSTBADJOB rises to .37 , which equals (with rounding)

$$
(.18)(0)+[1-.96](1)+[(.96-.18)(.35)+.07] .
$$

Thus, an otherwise median judge who, sitting alone, acquits a defendant spends on average an extra 1.4 years in branch offices.

The components of the predicted value in equations (18) and (19) also have meaning. The probability that the judge spends 0 percent of his next decade in branch offices after the acquittal falls from .38 to .18 , and the probability that he spends 100 percent rises from .01 to .04 . The last term of the equations, less easy to interpret, represents the change in the expected time conditional on not spending 0 or 100 percent of the decade in branch offices, a probability which from .61 to .78 .

The puzzle is what to make of this. On the one hand, the difference between the not-quitesignificant results for ANYACQ and strongly significant ones for SOLOACQ could reflect the fog involved in collegial panels. Many of the acquitting panels might have been split. Because Japanese lower courts never publish dissents (though the Supreme Court does), we would not know which of the judges favored acquittal and which opposed. Because the judges themselves knew, however, the internal personnel reports might well reflect that information. If so, then the Secretariat might well punish only the two judges who favored acquittal. Accordingly, perhaps the contrast between the two sets of regressions simply results from the fog in the ANYACQ variable.

Alternatively, the difference between Regressions 2.2 and 2.4 might reflect a policy mandating that judges forward hard cases to a multi-judge panel. ${ }^{39}$ If so, then perhaps the Secretariat had no intent to punish judges who acquit after group deliberation. Instead, it wanted to punish those who flouted court policy and refused to forward ambiguous cases to three-judge panels. Perhaps, in short, the Secretariat did not punish judges for acquitting; it punished them for ignoring case-routing policy.

c. REV-ACQ. The SOLOACQ results thus leave a puzzle: whether the career penalties paid by judges who acquit on single-judge panels reflect (i) penalties for acquitting or (ii) penalties for not forwarding hard cases to collegial panels. Because even a Secretariat with a pro-conviction bias might see some acquittals as proper and not want to reward all convictions, we explore the careers of judges who find their cases reversed. If the Secretariat punishes only for case-routing violations rather than acquittals, then judges who find acquittals reversed should do no worse than those who find convictions reversed - holding constant the effect of SOLOACQ.

To explore these issues, we divide all appealed cases into four groups: acquittals reversed, acquittals affirmed, convictions reversed, and convictions affirmed. We then rerun the regressions with POSTGOODJOB and POSTBADJOB as the dependent variables. As the coefficients on these opinion variables are all insignificant in the POSTGOODJOB regressions, we omit the results here.

${ }^{39}$ Note that the Secretariat will always hold strong priors that a prosecuted suspect is guilty, quite rationally. This follows from the prosecutor's incentive to economize on his resources by only prosecuting guilty suspects. This idea is explored in Eric B. Rasmusen, Predictable and Unpredictable Error in Tort Awards: The Effect of Plaintiff Self Selection and Signalling, 15 Int'l Rev. L. Econ. 323 (1995). 
In Regression 3.1 we show the result a judge faces if he finds an acquittal overturned: over the next 10 years, he will spend substantially more time in branch offices. With a t-statistic of 2.52, the result is significant at the 1.2 percent level.

By itself, Regression 3.1 does not necessarily show a pro-conviction bias. Instead, it could reflect a general Secretariat policy of punishing judges who make mistakes - and a reversal indicates that the trial judge was wrong. Accordingly, in Regression 3.2 we use all four appeal-related variables.

The results show a stark bias: the Secretariat only punishes judges who find their acquittals reversed. Only the coefficient on ACQ-REV is either large or significant. In terms of judicial bias, the relevant question is whether the coefficient on ACQ-REV is greater than that on CON-REV. Indeed, it is --.329 for ACQ-REV compared to .002 for CON-REV.

It remains possible that the penalty paid by judges who find their acquittals reversed merely reflects the penalty paid by single-panel judges who (to continue the earlier argument) failed to follow the policy of forwarding hard cases to three-judge panels. Given that the correlation between ACQ-REV and SOLOACQ is only .11, we were skeptical. Yet to test for that phenomenon directly, in Regression 3.3 we include both the four appeal-related variables and SOLOACQ.

The results in Regression 3.3 confirm the independent bias against those who write reversed acquittals. Both ACQ-REV and SOLOACQ are independently significant. Holding constant the effect of SOLOACQ, judges who find their acquittals reversed still suffer larger penalties over the next decade.

As before, the tobit coefficients need some manipulation before they can be interpreted for more than just statistical significance. We will not lay out the calculations in such detail as we did for Regression 2.4. Regression 3.3 yields a predicted value of POSTBADJOB for the median judge of .22. The median judge had no acquittals reversed or solo acquittals. For a judge with a three-judge panel acquittal reversed, our prediction rises to .42, an extra 2 years in branch offices over the decade. For a judge with a solo acquittal that was later appealed and affirmed, our prediction is .44. This is surprising-- a judge is punished heavily for a solo acquittal even if his judgement is later confirmed by the appellate court. Rather less surprising, a judge who both acquits in a solo trial and is later appealed against and reversed has a predicted percentage of time in branch offices of .59--- a full 3 years more than the median judge in our sample. 
Table 3: The Effect of Appeals on Judicial Careers

\begin{tabular}{|c|c|c|c|c|c|c|}
\hline & \multicolumn{2}{|c|}{$(3.1)$} & \multicolumn{2}{|c|}{$(3.2)$} & \multicolumn{2}{|c|}{$(3.3)$} \\
\hline LHS: & POSTBADJOF & & POSTBADJC & & POSTBADJC & \\
\hline Intercept & $.358 * \star \star$ & $(5.64)$ & $.340 * \star \star$ & $(5.21)$ & $.330 * \star \star$ & $(5.11)$ \\
\hline PREBAD JOB & $.333 * \star \star$ & $(2.98)$ & $.336 * \star \star$ & $(3.01)$ & $.312 \star \star$ & $(2.82)$ \\
\hline SENIORITY & $-.024 * \star \star *$ & $(7.14)$ & $-.024 * * *$ & $(7.16)$ & $-.023 * \star *$ & $(7.08)$ \\
\hline FLUNK & .006 & $(0.74)$ & .005 & $(0.70)$ & .004 & $(0.58)$ \\
\hline ELITEU & -.064 & $(1.21)$ & -.072 & $(1.35)$ & -.072 & $(1.38)$ \\
\hline $1^{\mathrm{ST}}-\mathrm{TOK}$ & $-.159 * *$ & $(2.01)$ & $-.161 * *$ & $(2.03)$ & $-.182 * *$ & $(2.31)$ \\
\hline OP INIONS/YR & -.005 & $(0.28)$ & -.003 & $(0.16)$ & .001 & $(0.05)$ \\
\hline YJL & $.153 * \star$ & $(2.13)$ & $.157 * \star$ & $(2.19)$ & $.155 * \star$ & $(2.19)$ \\
\hline ACQ-REV & $.306 * *$ & $(2.52)$ & $.329 * * *$ & $(2.69)$ & $.301 * *$ & $(2.48)$ \\
\hline $\mathrm{ACQ}-\mathrm{AFF}$ & $\mathrm{XXXXXXXXX}$ & $\mathrm{XXXXXXX}$ & .108 & $(0.96)$ & .108 & $(0.98)$ \\
\hline CON-REV & XXXXXXXXX & XXXXXXX & .002 & $(0.02)$ & .014 & $(0.13)$ \\
\hline $\mathrm{CON}-\mathrm{AFF}$ & $\mathrm{XXXXXXXXX}$ & $\mathrm{XXXXXXX}$ & .088 & $(1.40)$ & .102 & $(1.63)$ \\
\hline SOLOACQ & $\mathrm{XXXXXXXXX}$ & XXXXXXX & 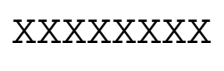 & $\mathrm{XXXXXX}$ & $.215 \star \star$ & $(2.18)$ \\
\hline Stan.Error & .37 & & .37 & & .36 & \\
\hline Pseudo $R^{2}$ & .17 & & .17 & & .19 & \\
\hline
\end{tabular}

Notes:

Coefficient, followed by the absolute value of the t-statistic.

*** -- significant at more than the 1 percent level.

** -- significant at more than the 5 percent level.

* -- significant at more than the 10 percent level.

The regression uses Tobit and there are 321 observations. In each regression, there are 134 observations censored because of the bound of 0 and 5 because of the bound of 1 on the left-hand-side variable. 


\section{Conclusions}

Japanese courts convict. Courts convict here too, of course, but in Japan they convict with a vengeance: over 99 percent of the time. Even in cases where the defendant contests his guilt, they convict over 98 percent of the time. Are courts convicting the guilty and innocent alike, or are prosecutors merely doing a marvellous job of choosing the cases to try? Absent independent evidence of the guilt of the accused, one cannot directly tell.

In this article, we pursue indirect evidence on point. First, Japanese prosecutors are woefully understaffed. Tied as they are to a severe budget constraint, one might expect them to try only the most obviously guilty. Unbiased courts would then convict. The conviction rate would approach 100 percent, but only because all of the defendants were guilty. To return to our heuristic in Figure 1, Japan would be at the best case row (a).

Crucially, Japanese courts are not unbiased. Instead, Japanese judges face significantly biased incentives: judges who acquit are significantly more likely to suffer a career penalty than those who convict. Were Japanese prosecutors prosecuting only the guilty one still might not much care, since the biased courts would nonetheless be convicting only the guilty (row (b) in Figure 1). Yet resource constraints will induce prosecutors to try only the obviously guilty if courts will refuse to convict defendants wrongly accused. If judges instead face strong incentives to convict, then even prosecutors subject to stringent resource constraints have less reason to try only the obviously guilty. After all, whether they try the obviously guilty or the possibly innocent, judges may dutifully convict.

If all this is true, then the high conviction rates in Japan may well reflect innocent convictions. Given the biased judicial incentives, Japan is not at row (a); given the high conviction rates, it is also not at row (c). If prosecutors need not try only the most obviously guilty, they may not even be at row (b). Instead, they may be at the row (d): prosecutors only haphazardly screen their cases, and judges dutifully convict them all. 


\section{$\underline{\text { References }}$}

Administrative Office of the U.S. Courts, Judicial Business of the U.S. Courts (Washington, D.C.: Administrative Office of the U.S. Courts, 1995)

Daiichi hoki shuppan, K.K., ed., Hanrei taikei CD-ROM [A Systematic Case Law: CD-ROM] (Tokyo: Daiichi hoki, biannually updated.]

Easterbrook Frank (1993) Criminal Justice as a Market System, 12 J. Leg. Stud. 289.

Foote, Daniel (1992) The Benevolent Paternalism of Japanese Criminal Justice, 80 Cal. L. Rev. 317.

Foote, Daniel (1992) From Japan's Death Row to Freedom, 1 Pac. Rim L. \& Pol'y J. 11.

Foote, Daniel (1993) "The Door that Never Opens"? Capital Punishment and Post-Conviction Review of Death Sentences in the United States and Japan, 19 Brooklyn J. Int'l L. 367

Haley, John Owen (1991) Authority Without Power: Law and the Japanese Paradox (New York: Oxford University Press, 1991).

Haley, John Owen (1995) Judicial Independence in Japan Revisited, 25 Law in Japan 1.

Homusho, Hanzei hakusho [White Paper on Crime] (Tokyo Okura sho, 1996).

Landes, William M (1971) An Economic Analysis of the Courts, 14 J. L. \& Econ. 61.

Langbein, John (1979) Land Without Plea Bargaining: How the Germans Do It, 78 Mich. L. Rev. 204.

Introduction, in Lawrence W. Beer \& Hiroshi Itoh. The Constitutional Case Law of Japan, 1970 through 199027 (Seattle: University of Washington Press, 1996)

Johnson, Elmer H. (1997) Criminalization and Prisoners in Japan: Six Contrary Cohorts (Carbondale: Southern Illinois University Press 1997).

Matsuo, Koya \& Masahito Inoue, eds. (1992) Keiji sosho ho hanrei hyakusen /The Code of Criminal Procedure: One Hundred Selected Cases] (Tokyo: Yuhikaku, $6^{\text {th }}$ ed., 1992).

Miyazawa, Setsuo (1991) Administrative Control of Japanese Judges, in Philip S.C. Lewis, ed., Law and Technology in the Pacific Community (Boulder: Westview Press, 1991). 
Prepared Statement of Senator Patrick Leahy, Ranking Member, Before the Senate Judiciary Committee Hearing on the Nomination of James K. Robinson to be Assistant Attorney General for the Criminal Division (Federal News Service, April 22, 1998).

Attorney says he'll be candidate for prosecutor, The Indianapolis Star, January 17, 1998, at N02.

Nihon minshu horitsuka kyokai, ed., Zen saibankan keireki soran: kaitei shinban /Biographical Information on All Judges: New Revised Editionl (Tokyo Konin sha, 1990).

Policing in Japan 3 (Albany: SUNY Press, 1992) (F.G. Bennett, Jr., transl.).

Posner, Richard A. (1973) An Economic Approach to Legal Procedure and Judicial Administration, 2 J. Legal Stud. 399.

Priest, George L. \& Benjamin Klein (1984) The Selection of Disputes for Litigation, 13 J. Legal Stud. 1.

Ramseyer, J. Mark (1994) The Puzzling (In)dependence of Courts: A Comparative Approach, 23 J. Legal Stud. 721 (1994).

Ramseyer, J. Mark \& Minoru Nakazato (1989) The Rational Litigant: Settlement Amounts and Verdict Rates in Japan, 18 J. Legal Stud. 263.

Ramseyer, J. Mark \& Minoru Nakazato (1998) Japanese Law: An Economic Approach, (Chicago: University of Chicago Press, 1998).

Ramseyer, J. Mark \& Eric B. Rasmusen (1997) Judicial Independence in a Civil Law Regime: The Evidence from Japan, 13 J. L. Econ. \& Org 259-286.

Ramseyer, J. Mark \& Frances M. Rosenbluth (1993) Japan's Political Marketplace (Cambridge: Harvard University Press, 1993)

Rasmusen, Eric (1995) Predictable and Unpredictable Error in Tort Awards: The Effect of Plaintiff Self Selection and Signalling, 15 Int'l Rev. L. Econ. (September 1995) 323-345.

Rasmusen, Eric (1998) Mezzanatto and the Economics of Self Incrimination, forthcoming, Cardozo L. Rev.

Saiko saibansho jimusokyoku, Shiho tokei nempo, Heisei 6-nen [Annual Report of Judicial Statistics, 1994l (Tokyo: Hosokai, 1994)

Shiho undo kenkyujo, ed., Osorubeki saiban [Fearsome Trials] (Tokyo: Zenbo sha, 1969). 
U.S. Dept. of Commerce, ed., Statistical Abstract of the United States (Washington, D.C.: U.S. Department of Commerce, 1996).

Watanabe,Yasuo, Setsuo Miyazawa, Shigeo Kisa, Shosaburo Yoshino \& Tetsu Sato (1997) Tekisuto bukku gendai shiho [Textbook: The Modern Judiciary] (Tokyo: Nihon hyoron sha, 3d ed., 1997)

van Wolferen, Karel (1989) The Enigma of Japanese Power (New York: Alfred A. Knopf, 1989).

\section{$\underline{\text { Opinions and Statutes }}$}

Saibansho ho [Courts Act], Law no. 59 of 1947, § 26.

Kuni v. Yusa, 2 Saihan keishu 1123 (Sup. Ct., Aug. 5, 1948). 